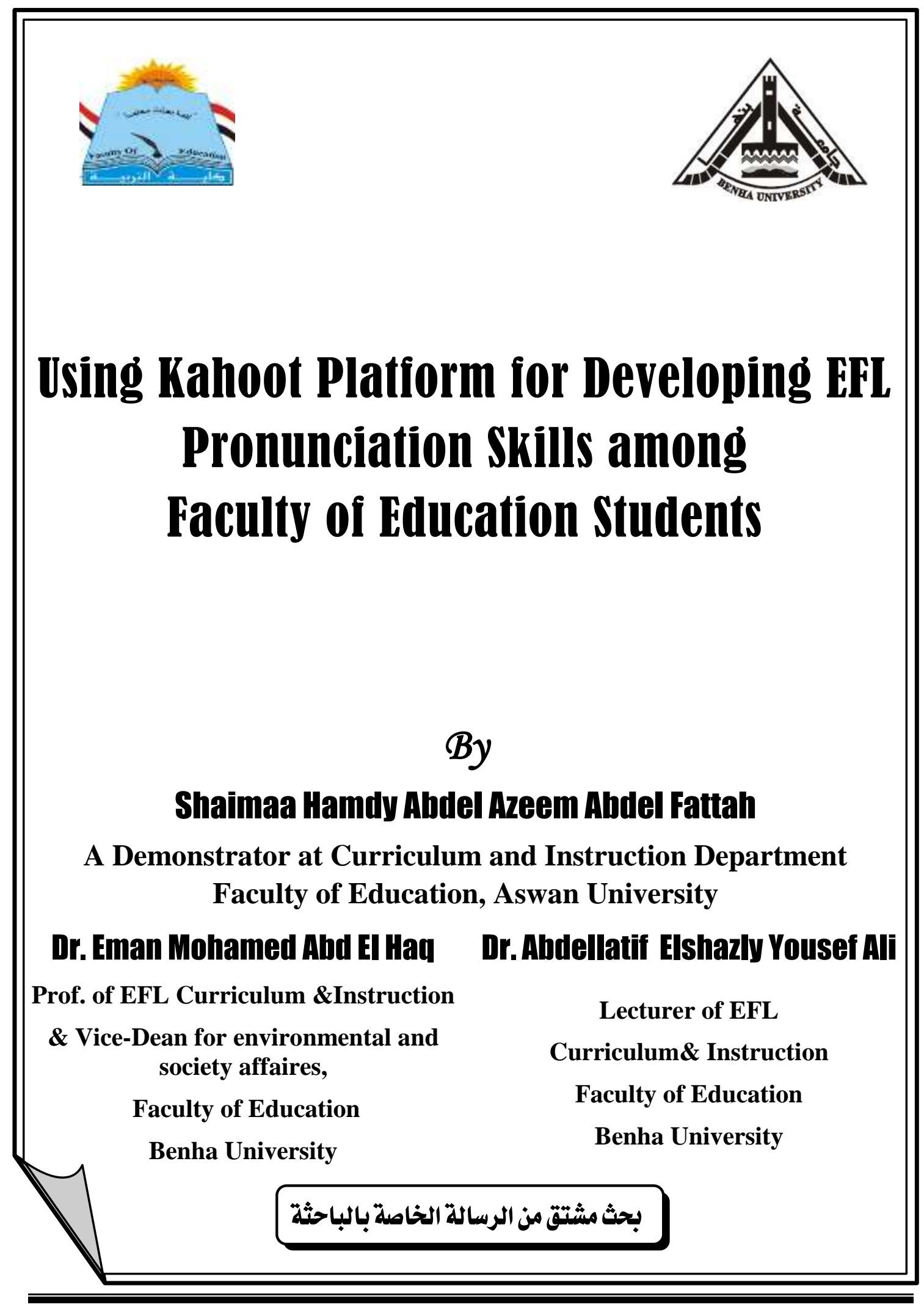




\section{Using Kahoot Platiorm for Developing EFL Pronunciation Skills among Faculty of Education Students}

By

\section{Shaimaa Hamdy Ahdel Azeem Abdel Fattah}

Demonstrator at the Department Of Curricula, Instruction and Educational Technology [TEFL]

\section{Dr. Eman Mohamed Ahd El Haq}

Prof. of EFL Curriculum \&Instruction $\&$ Vice-Dean for environmental and society affaires, Faculty of Education Benha University

\section{Dr. Ahdellatif Elshazly Yousef ali}

Lecturer of EFL

Curriculum\& Instruction

Faculty of Education

Benha University

\section{Abstract}

The aim of the present study was to investigate the effectiveness of using Kahoot platform for developing EFL pronunciation among Faculty of Education students. The participants of the study included (30) students (in each group) enrolled at the English section at faculty of Education, Benha University. The instruments of the study included a list of EFL pronunciation skills required for first year students and an EFL pronunciation test. The study followed the two groups (control and experimental) pre-post test design. In this design, the dependent variable is measured before and after the experiment for both groups. The EFL pronunciation test was administered to the students of both groups at the beginning. After the experimental group was taught using Kahoot platform, the EFL pronunciation test was post administered to both groups. The results were statistically analyzed (t-test) and the findings revealed that the EFL pronunciation skills of the experimental group were developed as a result of using Kahoot platform. It is recommended that Kahoot platform should be used in different educational stages for developing EFL pronunciation skills.

Keywords: Kahoot platform and EFL pronunciation skills.

$$
1
$$


يهدف هذا البحث الى معرفة مدى اثر استخدام منصة الكاهوت كأداة فى تتمية مهارات

النطق فى اللغة الانجليزية لاى طلاب الفرقة الاولى شعبة اللغة الانجليزيـة بكلية التربية جامعة بنها. و لقد تم استخدام التصميم التجريبي ذو المجموعتين (التجرببية و الضـابطه) و لقد بلغت عينة الدراسة ثلاثون طالب بكل مجموعة من طلاب الفرقة الاولى شعبة اللغة الانجليزية و تم تصميم قائمة بالمهارات اللازمة لهؤلاء الطلاب لمعرفة مدى توافر هذه المهارات لديهم؛ كما تم تحكيمها بواسطة عدد من المحكمين الخبراء فى مجال المناهج و طرق تدريس اللغة الانجليزيـة. وقد تم تصميم اختبار قبلى بعدى لقياس مهارات النطق لدى العينة. حيث تم اختبار الطلاب قبليا لتحديد مستوى أدائهم القبلى ثم تدربيهم عن طريق استخدام منصـة الكاهوت على كيفية النطق الصحيح ثم اعادة تطبيق الاختبارعلى الطلاب لقياس مدى التقدم فى مستوى أدائهم. و لقد أثتتـ النتائج عن وجود فرق فى أداء الطـلاب فى المجموعة التجربيية و الضـابطة فى التطبيق القبلي و البعدى لصالح المجموعة التجربية مما يدل على مدى فاعلية استخدام منصـة الكاهوت لتنمية مهارات النطق فى اللغة الانجليزية كلغة أجنبية.

كلمات مفتاحية: منصة الكاهوت، مهارات النطق فى اللغة الانجليزية. 


\section{Introduction}

Pronunciation is an integral part in learning English language as a foreign or second language. It is considered as a main aspect in communication between the learner and the teacher. Without good pronunciation the teacher will not be able to understand what the learner wants to say. Many students are proficient at grammar and have a huge amount of vocabulary, but when pronouncing English words they will not get understood. So, many researchers dealt with pronunciation skills and assigned many definitions, for example, Burns and Claire (2003,p.5) mentioned that pronunciation refers to the phonology of the language or the meaningful perception and production of the sounds of that language and how they impact on the listener . Seidlhofer (2001,p.56) added that when talking about pronunciation in language learning, it means the production and perception of the significant sounds of a particular language in order to achieve meaning in contexts of language use. In addition, Richards and Renandya (2002) stated that pronunciation is also known as phonology that includes the segmental level such as the role of individual sounds and sound segments as well as the suprasegmental features as stress, rhythm and intonation .

Paulston and Bruder (1976) stated that there are five stages in a pronunciation lesson. These stages can differ according whether the teacher is teaching a segmental or suprasegmental feature. These basic steps include a) Selection and presentation as pronunciation is best presented when the teacher presents one segmental or suprasegmental feature in one session. Presenting more than one may cause some difficulties and confusion for students. The teacher must make sure that he is introducing one sound and that students are concentrating with the sound. It is supposed to use native language at this stage. The teacher must make sure of some things. The first is that he must introduce a new vowel with previously learned consonants and vice versa. The second is to make sure that the sound is presented in all cases including initial, medial and final. 
Aural recognition and discrimination which means that students whose mother tongue is missing some sounds or features of the second or foreign language feel it difficult or challenging to recognize a new sound. For example, Kelly(2000) outlines some of the main difficulties which speakers of Arabic can have when speaking and pronouncing English sounds. These difficulties may include phonemes such as $/ \mathrm{P} / / \mathrm{b} /$ and $/ \mathrm{v} /$ and some vowels and diphthongs such as /e/. It is supposed that, such students may not be able to produce a new sound unless they can recognize or hear it at first. But it is a good chance to let students discriminate between similar and familiar sounds such as /s/ and / $\mathrm{z} /$. The discrimination exercise should not take more than five minutes. There are many techniques the teacher may use to practice discrimination. One technique is to keep the target sound in a specific position in all the examples he gives to the students. For example, beat-bit, Meat-Mit and heat-hit.

Production which refers to that when the teacher makes sure that students can discriminate between similar sounds, he must start asking them to produce it. Students must begin producing the sound in isolated words than phrases then sentences and finally in communicative utterances or contexts and situations. In this stage, the teacher plays the role of a model and students have to imitate the sound produced by the teacher. Here, the teacher must be aware of allowing all students in the class to hear the sound clearly. D) Contextualizing the practice is the step of practicing the sounds in isolation to become a practice in sentences. The classroom practice must contain exercises where the focus is on the meaning of the sound rather than the sound itself. One way of having students practice the sound in sentences is by asking questions. Discussion-type questions are excellent for practicing real communication. e) Sound-symbol correspondence which happen after the students have practiced producing the sounds, they are given the different spellings of this sound in general and exceptions. For example, /n/ sound they practice the production of the sound in words like knot and mnemonic. 
Pronunciation have some methods and techniques like other language skills. Overtime, pronunciation started to be included in the following methods mentioned by Richards and Kodgers, 2001:

\section{a) The direct method:}

It was found in the late 1800s and early 1900s by the German scholar F. Frankie. According to Frankie the best use of a language is to be used actively in the classroom instead of using explicit information to practice a language. In this method, pronunciation is taught to learners through imitation and learners have to listen and imitate the model they are listening to either this model was the teacher or recording. This method belongs to the energetic imitative approach. This Method has many drawbacks. One of them is that it requires native teachers as it depends mainly on the teachers' skills not the text book.

\section{b) The audio lingual method:}

This Method emerged during the 1940s and 1950s in which pronunciation is taught explicitly from the beginning. It looks like the direct method in which learners have to listen and imitate the model but here with the teacher giving explicit information from phonetics such as charts. This method has close relation to the analytic linguist approach. It also depends mainly on the techniques such as minimal pair drill in which group of words are the same in all sounds except one single sound in the same position (Celce-Murcia, Brinton \& Goodwin,1996,p.3).

\section{c) Community language learning(CLL):}

This method was developed by Currant 1976. In this method, the teacher and the learners' roles are redefined. The teacher can be seen as the counselor and the learner as client in the language classroom. The procedures of CLL can be derived from councelor-client relationship. This basic technique in all pronunciation practice is listening and imitating in which students listen and repeat a model. This model may be either a native or non-native teacher or recorder. This model gives learners some confidence to talk independently later on (Tench,2005). 
The following procedures are generally considered effective in teaching pronunciation to Arab learners of English(Betti and AlJubouri,2015, cited in Al-Khafaji ,2016):

a) At first the teacher has to identify the pronunciation problem and introduces it to the students.

b) The teacher shows the students a list of words containing the target sound which represents their problem. He may use minimal pairs. After that he has to conduct an oral drill. The teacher, here, may use props or explanatory diagrams or signals or tape recorder or any other techniques.

c) The teacher puts some of the given minimal pairs into phrases and sentences, then by using any technique as in step 2 , he may ask students about the sound they listen to. If they got it, they have to try producing it.

There are many factors affecting pronunciation learning. Kenworthy(1987:4) have identified six main factors affecting pronunciation learning. These are:-Native language, the age factor ,amount of exposure ,phonetic ability, attitude and identity, motivation and concern for good pronunciation (Nation \& Newton,2009).

At first, Kenworthy explained that the native language of the learner of English pronunciation is the most influential factor. The more differences found between the sound system of English and other languages, the more difficulties the learner will face in pronouncing English. It can be done in three ways :

a) When there is an absent sound in the learners' native language, the learner may not be able to produce the sound.

b) When the rules of combining sounds into words are different from those of the native language, it may cause problems.

c) Since the rhythm and melody of a language determine its pattern of stress and intonation, learners may transfer these patterns into the target language. 
Secondly, the age is another important factor because as people age we left the ability to learn whenever it is live education is better. Thirdly, motivation and concern for good pronunciation means that being able to acquire a good pronunciation and asking for correcting mistakes in speech without embarrassment affect pronunciation learning. It means that the extent of learners' motivation is the thing that propels them toward the improvement in pronunciation. Fourthly it is clear that good discriminators are able to benefit from pronunciation drills, while discriminators do not seem to benefit from drills very much. This factor is called phonetic ability or the auditory discrimination ability. It means having an "ear" for language.

Then, the amount of exposure as the more exposure that one gets makes it easier to acquire good pronunciation.Finally, the attitude and identity factor refers to many non-linguist factors in which one's attitude toward speakers of the target language, the development of pronunciation skills(Afshari \& Ketabi, 2017 and Wibawa, 2014).

Teaching pronunciation is a prominent in foreign language teaching. In spite of this, pronunciation has somehow become the most neglected and excluded component of language teaching and learning (Shahzada,2012 and Underhill, 2013). Gilakjani and Ahmadi(2011) and Woloshen, (2013) asserted that teaching pronunciation is granted the least attention in many English language classrooms.

According to Kelly (2000), pronunciation is neglected in language classrooms and this fact arises from the teachers' doubt of how to teach it rather than their lack of interest in the topic. According to previous studies (Macdonald, 2002 and Derwing and Munro, 2005), teaching pronunciation is ignored within the English as a foreign / second language (EFL/ESL) classroom context, teacher training programs and course materials. However, pronunciation instruction is regarded as extremely beneficial from learners' perspective (Barrera Pardo, 2004). 
As technology has become more readily available to the general public, teachers have attempted to use it in many ways to improve students pronunciation of second and foreign languages (Aguilar,2007). Neri,Cucchiarini and strik (2002) and Neri,Cucchiarini,Strik and Boves (2002) mentioned that there are a lot of benefits in computer assisted pronunciation instruction which cannot be found in traditional teaching approaches. Students can have access to unlimited input through using digitized pronunciation software individually. It also provides them with individualized feedback automatically.

There are a number of interventions that have shown to improve pronunciation skills. So, there is a need to use different techniques and tools to develop it such as Kahoot platform.

Traditional means of learning restrict the learner to certain learning methods, at a specific time and place whereas e-learning services create wider horizons for organizations and individuals who are involved in the learning process. Piezunka (2011) said that these environments facilitate the delivery of the learning materials so the learner can access them at home or at the office. The concept of a platform describes a set of system components that is strongly interdependent with most other system components. This concept underlies all kinds of technology-based products, collaborations that produce multi-product systems, and transactions between distinct sets of market participants.

Over the past years several technical aids promoting active learning have been developed, ranging from interactive learning platforms used to communicate with students, making assignments, making power point presentations and other learning material available (e.g. Fronter and Canvas) to aids applied directly in the teaching situation, that is, student response systems like clickers, Kahoot!, and Socrative. The use of student response systems has increased rapidly in higher education (Kay \& LeSage, 2009). 
Kahoot is a classroom response system which creates an engaging learning environment, through a game based digital pedagogy. It is an easy-to-use blended learning platform which works on any internetenabled device that helps making the classroom and the learning environment a different one from the traditional. It helps turning the classroom into an interactive, encouraging and engaging environment. It also helps educators and learners to ask great questions as well as feel that they are playing and forget that they are actually learning as they are fully engaged in the game (Kahoot, 2015).

Plumb (2017) mentioned that Kahoot is an online educational application that depends on student response system, it is like the so called clickers but Kahoot is the up to date technology in the same field with some advantages in Kahoot including being free, easy and engaging. It can be used by teachers to create three types of activities either quizzes, discussions or surveys. Also, it doesn't require that students have to create an account to participate in any kind of the activities but the teachers have to create an account to form the quizzes, discussions and surveys that are suitable for their classes.

Some advantages of using Kahoot is that, Kahoot is free, easy for students to learn, doesn't require students to do any registeration, compatible with any smartphone, tablet or computer, gives instant feedback and improve the students' excitement and engagement. All these advantages are related to the students and the learners. Kahoot has also some advantages for the instructors . As Kahoot helps instructors when they want to download, review and save students results, it helps them in creating quizzes, discussion questions and surveys and it helps also in adjusting the response time (Plumb \& LaRosa, 2017).

Any educational game must contain certain qualifications to be effective as well as successful, it must have the right context, the right cognitive activities, meaningful challenges and feedback (Kapp, 2012). 
Therefore, Nicol and Macfarlane-Dick (2006) mentioned a list of seven principals for good feedback practice:

1- Helping clarify what good performance is.

2- Delivers high-quality information to students about their learning.

3- Encourages teacher and peer dialogue around learning.

4- Encourages positive motivational beliefs and self-esteem.

5- Provides opportunities to close the gap between current and desired performance.

6- Provides information to teachers that can be used to help shape the teaching.

Kahoot can help students and learners create a new way of assessing their knowledge. Kahoot with its different types of activities such as quizzes, discussions and surveys can create an increase in the students' attitudes towards what they learn as well as their participation in the class and the learning process as a whole (Omar, 2017). Wang and Lieberoth (2016) stated that Kahoot is an educational tool for creating quizzes with the ability to add audio and video materials such as pictures, audio files and yootube videos to the questions. It also enables the teacher to publish and share the quiz made made by the teachers as well as edit others' quizzes.

Siegle (2015) added that teachers can select and determine the amount of time given to each question. Students join the game through a game code and are able to create their names or even their nick names. The invitation screen with the game pin, if a student registered with an inappropriate name the teacher can just click on his name to remove the player from the game. When all students join the game and are ready for playing the game, the teacher can just click on start now to start the game. As the teacher started to display questions on the screen, the students begin clicking on the right answer and at the end the teacher can present a list of all the participants as well as their responses. 
Discussions at Kahoot has a little bit different style. The teacher can create only one question or only one topic and with no right or wrong answer and there are no points put intentionally for the question but there is a limited period of time which can be used in debate as well as any oral skill. Similarly, surveys on Kahoot do not have a specific answer which is wrong or right and the survey may contain more than one question (Graham, 2015).

There are a number of studies which proved the effectiveness of using Kahoot such as: Wang (2015) hence carried out a quasi experimental design, comparing students who were exposed to Kahoot! in a single motivational lecture versus students where Kahoot! was used in every lecture for five months. Results indicated that the competitive nature of Kahoot! buffered against a wear off effect. Kahoot! therefore seems like a promising tool to adjust teaching to students' levels of knowledge, and in promoting active learning in a lecture setting.

Bicen and Kocakoyun (2017) conducted a study to find which application in gamification is preferred by students. The sample was about 130 studentsm, the findings revealed that Kahoot was the most preferred application by students. Another study was conducted by Medina and Hurtado (2017) to explore the use of Kahoot on developing the learning of vocabulary in an English class. The results showed that using Kahoot increased the learners' engagement, interaction and motivation as well as the vocabulary acquisition. This study also suggested to use classroom technology in language classrooms to improve learning.

Licorish, George, Owen and Daniel (2017) conducted a study to find out the effect of a game based student response system Kahoot in engaging studentsduring lectures. The findings revealed that the use of Kahoot enriches the quality of student learning in the classroom as well as the high effect on engagement, classroom dynamics, motivation and learning experience. 


\section{Context of the problem:}

In spite of the importance of EFL pronunciation skills, there is a lack in them among first year students at Faculty of Education (freshmen). Many researchers investigated the weakness of pronunciation skills among students in all stages. For example, Abd Elmaksoud (2013) assured that most students are in a bad need for a program to develop their pronunciation skills. Also Mohamed (2010) asserted that third year faculty of education students are in a need for phonetic development.

Previous studies concerning the Egyptian context indicate that the Egyptian students have poor mastery of pronunciation skills (Badr, 2009 ; Hassan, 2009; Abd El-Razek, 2010; Suleiman, 2011 ; Helwa, 2013; Mohammed, 2013 and El Sayed, 2014). They conducted these studies on different samples in different stages and introduced solutions for the lack found in pronunciation skills.

As Egyptian learners of English face problems and the majority of these problems are related to pronunciation. Wahba(1998) summarizes these problems:

Egyptian students face certain problems related to pronunciation. Some of these problems are related to stress, others are related to intonation. However, most of these problems can be attributed to differences in pronunciation between English and Arabic (p.36).

To document the problem of the present study, the researcher conducted a pilot study on a sample of 20 first year students enrolled at the English section at Benha faculty of education in December,2015. The pilot study consists of a pronunciation test. The test includes two main questions. The first question asked students to say five sentences correctly and the second question asked students to read a passage while paying special attention to word and sentence stress, variety in pitch, intensity and intonation. The test was adopted from section one of Helwa (2013). The results of the pilot study revealed that most of the students 
were not pronouncing accurately. Their speaking was filled with pronunciation mistakes. About $75 \%$ of students were not able to speak with good and accurate pronunciation .To sum up, first year students enrolled in English section faculty of Education, Benha University lack EFL pronunciation skills, so the researcher suggests using Kahoot platform for developing their EFL pronunciation skills .

\section{Statement of the Problem:}

In spite of the importance of the EFL pronunciation skills and the need for enhancing them among first year students at faculty of education, they seem to lack these skills. Thus, there is a need for an effective program for developing some EFL pronunciation skills among first year students at the faculty of Education. So, the following study aimed at examining the effectiveness of using Kahoot in developing EFL pronunciation skills.

\section{Questions of the Study:}

To investigate this problem, the present study attempted to answer the following questions :

1- What are the pronunciation skills required for first year students at Faculty of Education?

2- What are the features of using Kahoot that are required for first year students at Faculty of Education?

3- What is the effect of using Kahoot in developing some EFL pronunciation skills among first year students at Faculty of Education?

\section{Delimitations of the study:}

The present study will be delimited to :

- A sample of first year students enrolled at English Section at the Faculty of Education, Benha University.

- Some EFL pronunciation skills required for first year students enrolled at the English section Faculty of Education at Benha University. 


\section{Procedures of the study:}

The following procedures will be followed to carry out the present study:

\section{1- Identifying the EFL pronunciation skills required for first year students students at faculty of education through:}

Reviewing the literature and the previous studies related to the EFL pronunciation skills and preparing a list of the EFLpronunciation skills required for first year students at Faculty of Education .Then, submitting the list to the jury members to verify its validity. Finally, modifying the list according to jury's recommendations and forming the list in its final form.

\section{2- Identifying the features of using Kahoot required for first year students at faculty of education through :}

Reviewing the literature and the previous studies related to Kahoot and identifying Objectives, content, activities, strategies and methods of evaluation of the program. Then, identifying the procedures and the evaluation techniques followed during implementing the program.

\section{3- Identifying the effect of using Kahoot on developing EFL pronunciation skills:}

Preparing a pronunciation test used as a pre and post test to the two groups and the rubric to assess the development of pronunciation skills. teaching to the experimental group using Kahoot while teaching the control group with the traditional way. Then, post-testing the two groups to evaluate the effect of the program used then collecting and analyzing the data statistically and interpreting the results of the study. Finally, presenting recommendations and suggestions for further Researches. 


\section{Participants of the study:}

The participant were thirty first year students enrolled at the English department at faculty of Education Benha University at the first semester of 2017-2018 academic year because they must be trained very well on how to pronounce correct English when they become teachers.

\section{Instruments of the study:}

- An English language pronunciation test prepared by the researcher for measuring students' pronunciation skills. It will be used as a pre and post test and a rubric to score it.

\section{The Validity of the EFL Pronunciation Test: $\square$}

In order to validate the EFL pronunciation test, it was submitted to some of the jury members in curricula and methods of Teaching English . They were requested to judge whether the test items were clear and appropriate to the study sample ( First Year English Department Students at Benha Faculty of Education) and whether the test items measure the EFL pronunciation skills that they are supposed to measure. They indicated the suitability of the test to its main objectives and the consistency of questions to the test's objectives. Jury members suggested some modifications and the researcher has taken them into account to get the final form of the test.

\section{The Reliability of The EFL Pronunciation Test: $\square$}

For estimating the reliability of The EFL Pronunciation Test ,the following two methods were used:

a) Alpha Cronbach method: It is a method to measure the internal consistency, that is, how closely related a set of items are as a group. It is considered to be a measure of scale reliability. It was calculated and computed in the present study and it was (.883). This means that the EFL pronunciation skills test is reliable. 
b) Inter-rater method: It means two or more raters/observers give consistent estimate of the same test and this method is used to avoid the subjectivity factors in grading. Accordingly, the researcher gave an English language instructor $\left(*^{*}\right)$ a copy of students' answers to the EFL pronunciation test and the rubric to estimate the student's answers.

\section{Aims of the study:}

The study aimed at developing EFL pronunciation skills for first year students enrolled in the English section, faculty of Education, Benha university. Therefor, the program was utilized to:

a) Identify the importance of EFL pronunciation skills to students as English language learners.

b) Develop EFL pronunciation skills in particular.

c) Improve their intelligibility of pronunciation skills.

d) Improve their communication skills to speak English accurately and fluently.

e) Work more independently.

\section{Duration of the edutainment based program:}

The program is intended to last for four weeks. In each week students have three sessions. Each session presents specific skills to be dealt with, and the time allocated for each session is 120 minutes.

\section{The Experimental Treatment:}

The Following procedures were conducted in the present study:

\section{a) Pre-testing:}

Having conducted the validity and reliability of the study tools. The researcher pre-tested the study participants using the EFL pronunciation test to measure their level in EFL pronunciation skills

* Ansam Mohamed Abd El Aziz, TEFL instructor at Benha University. Ghada El Sadek Abd Allah, TEFL instructor at Benha University. 
before implementing the program. The pre-testing took four days for both the control and the experimental groups. The researcher administered the EFL pronunciation test to both groups before the experiment. Instructions were given orally by the researcher of the present study. The participants' answers were videotaped in order to be analyzed and scored. Pre-test statistics revealed that the study participants encountered difficulties in EFL pronunciation skills.

\section{b) Experimentation of the Program:}

After pre-testing, The program was administered to the study participants $(\mathrm{N}=30)$ by the present study researcher. The program lasted for four weeks with three sessions per week and each session lasted for about two hours. At the beginning of the program, the objectives, importance and characteristics of the program were presented to the study sample. After the introductory session, the rest of the instructional sessions were introduced to the study sample. At the beginning of each session, the participants were informed about the role of the teacher, the role of the students, the instructional materials and the various tasks. At the end of each session, the researcher assigned the study participants some online and offline activities related to what they had learned in order to make sure that they have mastered the skills of each session. At the end of the program, the participants' progress in EFL pronunciation skills was checked after the implementation of the program using the EFL pronunciation test .

\section{c) Post-testing:}

The researcher posttested the study participants, after conducting the experiment. Using the same instrument (the EFL pronunciation test). Post-testing the participants of the study was to investigate the effectiveness of the program. 


\section{Evaluation of the edutainment based program:}

The evaluation system used in this program included both formative and summative evaluation.

\section{d) Formative Assessment:}

Formative evaluation was used for assessing the participants' progress in EFL pronunciation skills and for providing necessary and immediate positive feedback. The activities and online quizzes provided the present study researcher with the sufficient information about the participants' progress and development in EFL pronunciation skills.

\section{e) Summative Assessment:}

Summative evaluation was conducted at the end of the experiment through the application of the EFL pronunciation test to measure the achievement of the intended topics of the program.

\section{Findings and Discussion of the Study:}

The overall aim of using Kahoot was to develop EFL pronunciation skills for first year students' enrolled in the English Section at Benha university Faculty of Education.

To measure the effectiveness of the program ,the two groups were pre-tested on the EFL pronunciation then post -tested using the pronunciation test .For comparing the initial and the final mean scores of the study sample in the overall EFL pronunciation skills and to find whether there were significant difference between them in the pre-post assessment of the test between the control and the experimental groups.

\section{Experimental and Control group in the pre-Post Test:}

The t-test is used to compare the mean scores of the study sample in EFL pronunciation test on the post assessment of the control and experimental groups. Table(1) presents the students' mean scores, 
standard deviation-value and the level of the significance of the study sample in the post assessment of the EFL pronunciation test.

\begin{tabular}{|c|c|c|c|c|c|c|c|}
\hline \multirow{3}{*}{$\begin{array}{c}\text { Overall EFL } \\
\text { Pronunciation } \\
\text { skills }\end{array}$} & groups & N. & Mean & S.D. & t- value & D. F. & Sig. \\
\hline & Control & 30 & 29.367 & 3.178 & & & \\
\hline & Exp. & 30 & 48.133 & 5.661 & 15.832 & 58 & 0.01 \\
\hline
\end{tabular}

This table indicates that the mean scores of the experimental group in the post application of the overall EFL pronunciation skills (48.133) are higher than the mean scores of the control group of the same test (29.367), t-value is (15.832), which is significant at the 0.01 level. The main hypothesis was confirmed.

The present study aimed at developing the study sample's EFL pronunciation skills through the use of Kahoot. Consequently, the EFL pronunciation skills of the participants in the experimental group were developed in the post assessment of the EFL pronunciation test than the post assessment of the control group due to the use of Kahoot.

\section{Conclusion:}

Based on the aforementioned results, it can be said that the participants' EFL pronunciation skills were developed after the implementation of the program. It is clear that the first main hypothesis and its sixteen sub hypothese were accepted. Accordingly, the significant differences found in favour of the experimental group in the post assessment of the EFL pronunciation skills test can be related to the implementation of the program which has proved to be effective.

Before the implementation of the program, most of the participants were found to lack EFL pronunciation skills and have many problems in pronouncing different words and sentences. However, after the implementation of the program, students themselves felt the 
improvement in their EFL pronunciation skills. Their errors decreased because of the continuous feedback the program presented resulting in an increase in EFL pronunciation skills.

By the end of the program the study, the participants reported that they have benefited from the program and reported that they have already noticed their improvement in EFL pronunciation skills. They also added that they want such a program to develop other English language skills.

\section{Recommendations of the study:}

\section{In the light of the findings of the study the following} recommendations may be presented:

1- Developers of English language curriculum should benefit from such programs.

2- Teaching and learning Pronunciation skills through using technology and should be emphasized.

3- Providing a fully engaging learning environment for students to acquire and practice language.

\section{Suggestions for further research:}

The following areas are suggested for further research:

1- Investigating the effectiveness of technology based programs in developing EFL other language skills among Faculty of Education students.

2- Investigating the effectiveness of technology based programs on special needs students.

3- Investigating the effectiveness of technology based programs in developing students' writing and creative writing skills.

4- Developing remedial courses based on technology activities for overcoming students` problem on the four language skills.

5- Reapplication of the study at various educational stages such as primary, preparatory and secondary stages.

6- A controlled research study addressing broader samples to increase the generalization of the findings. 


\section{References}

- Afshari,S. \& Ketabi,S. (2017). Changing paradigms in teaching English pronunciation: A Historical overview. International Journal of research studies in language learning,6(2) ,P.69-81.

- Aguilar,F. (2007). Top of the pods in search of a podcasting pedagogy for language learning. Computer Assisted Language Learning, 20(5) ,P.471-492.

- Al-Khafaji,A.K.A. (2016). The effectiveness of a program based on the pronunciation skills of the English language on developing some oral communication skills for the Iraqi students at the university level. Unpublished Doctoral Dissertation. Ain Shams university,Egypt.

- Barrera Pardo, D. (2004). Can pronunciation be taught? A review of research and implications for teaching. Revista Estudios Ingleses, 17, 6-38

- Bicen, H. \& Kocakoyun, S. (2017). Determination of university students' most preferred mobile application for gamification. World Journal on Educational Technology: Current Issues. 9(1), 18-23.

- Burns,A.\&Claire,S. (2003) . Clearly speaking pronunciation in action for teachers. Macquire University, Sydney : National Centre for English language teaching and research.

- Celce-Murcia,M. ,Brinton,D., \& Goodwin,J.M. (1996). Teaching pronunciation: A Reference for teachers of English to speakers of other languages.Cambridge University Press.

- Derwing, T. M., \& Munro, M. J. (2005). Second language accent and pronunciation teaching: A research-based approach. TESOL Quarterly, 39(3), 379-397

- Gilakjani,A.P.\&Ahmadi,M.R. (2011) . Why is pronunciation so difficult to learn?. English language teaching,4(3), 74-82.

- Graham, K. (2015). TechMatters: Getting into Kahoot!(s): Exploring a game-based learning system to enhance student learning. LOEX Quarterly, 42(3), 4. 
- Kahoot! Game-based blended learning \& classroom response system. (2014). Retrieved,from https://getkahoot.com

- Kapp, K. (2012). The gamification of learning and instruction: Game-based methods and strategies for training and education. San Francisco, CA: Pfeiffer.

- Kay, R. H., \& LeSage, A. (2009). Examining the benefits and challenges of using audience response systems: A review of the literature. Computers \& Education, 53(3), 819-827.

- Kelly, G. (2000). How to teach pronunciation (J. Harmer, Ed.). England: Longman.

- Kenworthy,J. (1987) . Teaching English pronunciation, Longman handbooks for language teachers, Longman. London and New York.

- Licorish, S. A., George, J. L., Owen, H.E. \& Daniel, B. (2017). “Go Kahoot!" enriching classroom engagement, motivation and learning experience with games. In Chen, W. et al. (Eds.), Proceedings of the 25th International Conference on Computers in Education. New Zealand: Asia-Pacific Society for Computers in Education.

- Macdonald, S. (2002). Pronunciation - views and practices of reluctant teachers. Prospect, 17(3), 3-18.

- Medina, E. G. L., \& Hurtado,C.P.R. (2017). Kahoot! A Digital tool for learning vocabulary in a language classroom. Revista Publicando, 4 No 12. (1),441-449.

- Nation, T.S.P. \& Newton, J. (2009). Teaching ESL/EFL Listening and Speaking. New York: Routledge.

- Neri,A., Cucchiarini,C., \& Strik,H. (2002). Feedback in Computer assited pronunciation training: when technology meets pedagogy in proceedings of CALL conference "CALL professionals and the future of CALL research", Antwerp, Belgium,(PP.179-188).

- Neri,A., Strik,H. \& Boves,L. (2002). The pedagogy- technology interface in computer assisted pronunciation training. Computer Assisted Language Learning, 15(5), P.441-467. 
- Nicol, D., \& Macfarlane-Dick, D. (2006). Rethinking technologysupported assessment practices in relation to the seven principles of good feedback practice. In C. Bryan \& K., Cleg (Eds.), Innovative assessment in higher education, (pp.1-14). London:Routledge.

- Omar,N.N. (2017). The effectiveness of Kahoot application towards student's good feedback practice. PEOPLE: International journal of social sciences, 3(2), 2551-2562.

- Paulston,C.B. \& Bruder,M.N. (1976). Teaching English as a second language, techniques and procedures. Winthrop publishers, Cambridge:Massachusetts.

- Piezunka, H. (2011). Technological platforms: An assessment of the primary types of technological platforms, their strategic issues and their linkages to organizational theory. State of the Art Artikel, 6, 179-226

- Plumb, C.M., \& LaRosa, J. (2017). Using Kahoot! in the classroom to create engagement and active learning: A Game-based technology solution for elearning novices. Management Teaching Review, 2 (2), 151-158.

- Richards, J. C. \& Renandya, W. A. (Eds). (2002). Methodology in language teaching. New York;Cambridge university press.

- Richards, J. C., \& Rodgers, T. S. (2001). Approaches and methods in language teaching. Cambridge University Press.

- Seidlhofer, B. (Ed.) . (2001) . Pronunciation. In Carter. R. and Nunan. D. (Eds.) ., The Cambridge guide to teaching English to speakers of other languages. New York, United States Of America: Cambridge University Press.

- Shahzada, G. (2012). Views of the teachers regarding the students' poor pronunciation in English language. Journal of educational and social research,2(1), 309-316.

- Siegle, D. (2015). Technology: Learning can be fun and games. Gifted Child Today,38(3), 192.

- Tench,P. (2005). Teaching pronunciation. Speak out,34, P.45-53. 
- Underhill,A. (2013) . Cinderella,integration and the pronunciation turn. Speak out,49, 1-5.

- Wang, A. I. (2015). The wear out effect of a game-based student response system. Computers \& Education, 82, 217-227.

- Wang,A.I. \& Lieberoth, A. (2016). The effect of points and audio on concentration, engagement, enjoyment, learning, motivation, and classroom dynamics using Kahoot. Paper presented at the $10^{\text {th }}$ European Conference on Game Based Learning (ECGBL), Paisley, Scotland. Retrieved from:

https://www.researchgate.net/publication/309292067_The_effect_of_ points_and_audio_on_concentration_engagement_enjoyment_learnin g_motivation_and_classroom_dynamics_using_Kahoot

- Wibawa, Y. K. (2014). Improving students' pronunciation through role plays for class VIIC at SMP N3 temple in the academic year of 2013/2014. Yogyakarta State University.

- Woloshen, S. K. (2013). Podcating to enhance pronunciation in second language learning. Published Master Thesis. Faculty of Education. Simon Fraser University. Canada. 